\title{
Development of Multilocus PCR Assays for Raffaelea lauricola, Causal Agent of Laurel Wilt Disease
}

Tyler J. Dreaden and John M. Davis, School of Forest Resources and Conservation, University of Florida, Gainesville 32611; Carrie L. Harmon, Department of Plant Pathology, University of Florida, Gainesville 32611; Randy C. Ploetz and Aaron J. Palmateer, Tropical Research and Education Center, University of Florida, Homestead 33031; Pamela S. Soltis, Florida Museum of Natural History, and Jason A. Smith, School of Forest Resources and Conservation, University of Florida, Gainesville

\begin{abstract}
Dreaden, T. J., Davis, J. M., Harmon, C. L., Ploetz, R. C., Palmateer, A. J., Soltis, P. S., and Smith, J. A. 2014. Development of multilocus PCR assays for Raffaelea lauricola, causal agent of laurel wilt disease. Plant Dis. 98:379-383.

Laurel wilt, caused by the fungus Raffaelea lauricola, is an exotic disease that affects members of the Lauraceae plant family in the southeastern United States. The disease is spreading rapidly in native forests and is now found in commercial avocado groves in south Florida, where an accurate diagnostic method would improve disease management. A polymerase chain reaction (PCR) method based on amplifying the ribosomal small-subunit DNA, with a detection limit of $0.0001 \mathrm{ng}$, was found to be suitable for some quantitative PCR applications; however, it was not taxon specific. Genomic sequencing of $R$.

lauricola was used to identify and develop primers to amplify two taxon-specific simple-sequence repeat (SSR) loci, which did not amplify from related taxa or host DNA. The new SSR loci PCR assay has a detection limit of $0.1 \mathrm{ng}$ of $R$. lauricola DNA, is compatible with traditional and real-time PCR, was tested in four labs to confirm consistency, and reduces diagnostic time from 1 week to 1 day. Our work illustrates pitfalls to designing taxon-specific assays for new pathogens and that undescribed fungi can limit specificity.
\end{abstract}

The ambrosia beetle symbiont, Raffaelea lauricola, is a unique pathogen of trees that has created an unprecedented phenomenon in American forests, laurel wilt $(10,15,19)$. Typically, ambrosia fungi are nonpathogenic or weakly pathogenic to their tree hosts $(19,27)$ but $R$. lauricola has challenged this paradigm in dramatic fashion. $R$. lauricola is transmitted by the Asian redbay ambrosia beetle (Xyleborus glabratus), which is not known to cause damage in its native range $(19,30)$. Less than 2 years after its appearance in an area, more than $92 \%$ of the redbays $>7.6 \mathrm{~cm}$ in diameter and $100 \%$ of those greater than $10.2 \mathrm{~cm}$ in diameter were killed $(10,12)$. As of August 2013, the disease was found in North and South Carolina and Georgia, across most of Florida (45 of the 67 counties), and in Mississippi and Alabama (39,31).

Laurel wilt affects members of the Lauraceae plant family, including redbay (Persea borbonia) $(9,10)$, swamp bay (P. borbonia var. pubescens) (23), silkbay (P. humilis) (18), sassafras (Sassafras albidum) (34), and camphor (Cinnamomum camphora) (35). Three shrubs (northern spicebush [Lindera benzoin], pondberry [L. melissifolia; endangered], and pondspice [Litsea aestivalis; critically endangered]) are also susceptible $(8,17,37)$. Substantial losses of a fruit crop, avocado (P. americana) $(20,25,28,29)$, are developing in commercial groves in Florida (29). In Florida alone, avocado is worth in excess of $\$ 60$ million annually, and more valuable production is threatened in California and Latin America (7).

Management of laurel wilt is limited to injection of trees with systemic fungicides prior to infection (24) and the judicious use of sanitation, particularly in avocado orchards (36). It has been demonstrated that the vector and fungus do not survive in wood that has been chipped (36). Thus, early detection of symptomatic trees

Corresponding author: T. J. Dreaden, E-mail: tdreaden@ufl.edu

* The $\boldsymbol{e}$-Xtra logo stands for "electronic extra" and indicates that five supplementary figures are available in the online edition.

Accepted for publication 24 September 2013.

http://dx.doi.org/10.1094/PDIS-07-13-0772-RE

(C) 2014 The American Phytopathological Society and subsequent sanitation may slow the development of laurel wilt epidemics, particularly in areas devoid of significant densities of natural hosts. Monitoring based on trapping the vector is problematic because trapping efficiencies for $X$. glabratus are poor and the disease often develops before it is detected. In addition, several additional potential vector species have been identified $(4,14)$.

Currently, diagnosis of laurel wilt requires recovery of $R$. lauricola on a semi-selective medium (29), followed by sequencing of the small subunit (SSU; 18s) or large subunit (LSU; 28s) of the ribosomal DNA (rDNA) or the demonstration of pathogenicity for examined isolates (unpublished data). No taxon-specific polymerase chain reaction (PCR) assay for the pathogen has yet been reported. The aim of this study was to develop reliable and accurate real-time and traditional PCR-based methods to identify $R$. lauricola and diagnose laurel wilt.

\section{Materials and Methods}

DNA extraction. The DNA extraction method for samples used in this study was adapted from Justesen et al. (21). Wood samples were ground using a mortar and pestle with liquid nitrogen. Fungal conidia or mycelia samples ( 10 to $50 \mathrm{mg}$ ) were lysed by adding 0.8 $\mathrm{ml}$ of extraction buffer and three cycles of freezing at $-80^{\circ} \mathrm{C}$ for 5 min followed by incubating at $65^{\circ} \mathrm{C}$ until thawed. The ground wood samples were suspended in $0.8 \mathrm{ml}$ of extraction buffer (Dsorbitol at $25 \mathrm{~g} \mathrm{liter}^{-1}$, N-lauroylsarcosine at $10 \mathrm{~g} \mathrm{liter}^{-1}$, hexadecyltrimethylammonium bromide at $8 \mathrm{~g} \mathrm{liter}^{-1}, 0.8 \mathrm{M} \mathrm{NaCl}, 20$ $\mathrm{mM}$ EDTA, polyvinylpolypyrrolidone at $10 \mathrm{~g}^{-1}$ liter $^{-1}$, and $0.1 \mathrm{M}$ Tris, $\mathrm{pH} 8)$ and $2 \mu \mathrm{l}$ of RNase $\mathrm{A}\left(100 \mathrm{mg} \mathrm{ml}^{-1}\right)$ was added; the mixture was inverted five times and incubated at $65^{\circ} \mathrm{C}$ for $25 \mathrm{~min}$. The mixture was cooled to room temperature and $0.8 \mathrm{ml}$ of chloroform was added; the result was inverted 30 times and centrifuged for $5 \mathrm{~min}$ at 16,000 relative centrifugal force (RCF). The supernatant was transferred to new 2-ml tubes, $20 \mu \mathrm{l}$ of proteinase $\mathrm{K}\left(20 \mathrm{mg} \mathrm{I}^{-1}\right)$ was added, and the suspension was inverted four to six times and incubated for $20 \mathrm{~min}$ at $55^{\circ} \mathrm{C}$. The tubes were cooled to room temperature and $0.8 \mathrm{ml}$ of chloroform was added; the tubes were then inverted 30 times and centrifuged for $5 \mathrm{~min}$ at 16,000 RCF. The supernatant was transferred to new 2 -ml tubes, one volume of ice-cold $100 \%$ isopropanol was added, and the tubes were inverted and centrifuged for $15 \mathrm{~min}$ at 16,000 
RCF. The DNA pellets were washed with $350 \mu$ of $75 \%$ ethanol and centrifuged for 5 min at 16,000 RCF; ethanol was removed, and then the pellets were air dried and resuspended in $100 \mu \mathrm{l}$ of Tris-EDTA buffer. PCR was conducted on all DNA extractions using the rDNA SSU primers NS1 and NS4 (40) to confirm that all DNA extractions contained amplifiable DNA before using. DNA from $R$. lauricola PL1390 culture was used to construct a serial dilution, which was used to determine the detection limit and as a positive control. DNA was obtained for $R$. brunnea, $R$. albimanens, $R$. ambrosiae, and $R$. tritirachium from the Centraalbureau voor Schimmelcultures and for $R$. canadensis C592, $R$. montetyi C2221, $R$. albimanens C2223, $R$. brunnea C2229, $R$. subfusca C2253, and $R$. fusca $\mathrm{C} 2336$ and $\mathrm{C} 2349$ from Dr. T. C. Harrington (Iowa State University).

SSU-based detection method. An alignment of multiple $18 \mathrm{~s}$ SSU rDNA sequences of $R$. lauricola and closely related species, retrieved from GenBank, was evaluated for potential $R$. lauricola taxon-specific PCR primer sites. Three primers-PCR primers LWD1 and LWD3 that matched only $R$. lauricola but later produced a false positive and were discarded, and a second set of qPCR primers, LWD3 and LWD4, that matched $R$. lauricola and $R$. brunnea-were designed. PCR conditions for LWD3 and LWD4 were optimized by testing a range $\left(50\right.$ to $\left.60^{\circ} \mathrm{C}\right)$ of annealing temperatures. The primers were also tested against DNA from an $R$. lauricola serial dilution, both redbay and avocado laurel-wiltdiseased (naturally infected and artificially inoculated with isolate PL159, respectively) and healthy wood, and DNA from related fungi: $R$. canadensis, $R$. montetyi, $R$. albimanens, $R$. brunnea, $R$. subfusca, and $R$. fusca. The thermocycling protocol was $95^{\circ} \mathrm{C}$ for 2 min, followed by 40 cycles of $95^{\circ} \mathrm{C}$ for $15 \mathrm{~s}, 56^{\circ} \mathrm{C}$ for $15 \mathrm{~s}$, and $68^{\circ} \mathrm{C}$ for $30 \mathrm{~s}$, with a melting curve analysis performed at the end. SYBR green was used as the detection method. The PCR mixture included $11.25 \mu \mathrm{l}$ of Eppendorf $2.5 \times$ Realmastermix/SYBR

Table 1. Isolates used to screen Raffaelea lauricola specific microsatellite primers

\begin{tabular}{|c|c|c|}
\hline $\begin{array}{l}\text { PL } \\
\text { number }\end{array}$ & Other names & Species or notes \\
\hline 1008 & & Paraphaeosphaeria sp. \\
\hline 1009 & CBS 271.70 & Raffaelea albimanens \\
\hline 893 & $\mathrm{C} 2750$ & R. amasae \\
\hline 894 & CBS 185.64 & R. ambrosiae \\
\hline 896 & $\mathrm{C} 2372$ & R. arxii \\
\hline 1194 & CBS 378.68 & R. brunnea \\
\hline 890 & $\mathrm{C} 2345$ & R. ellipticospora \\
\hline 891 & C2394 & R. fusca \\
\hline 159 & Avocado B & R. lauricola Duval County, FL \\
\hline 388 & Pierce County & R. lauricola Pierce County, GA \\
\hline 570 & MK1 & R. lauricola Clay County, FL \\
\hline 571 & MK2 & R. lauricola Clay County, FL \\
\hline 692 & & R. lauricola Appling County, GA \\
\hline 716 & MS2 & R. lauricola Jackson County, MS \\
\hline 717 & MS3 & R. lauricola Jackson County, MS \\
\hline 735 & Columbia County & R. lauricola Columbia County, FL \\
\hline 1467 & CBS 129007 & R. lauricola Japan \\
\hline 1468 & CBS 129001 & R. lauricola Taiwan \\
\hline 1469 & CBS 129006 & R. lauricola Taiwan \\
\hline 1007 & $\ldots$ & $\begin{array}{l}\text { R. lauricola } \\
\text { from Ambrosiodmus lecontei }\end{array}$ \\
\hline 894 & $\mathrm{C} 2221$ & R. montetyi \\
\hline 1001 & 1073 & Raffaelea sp. \\
\hline 1002 & 1080 & Raffaelea sp. \\
\hline 1003 & 1081 & Raffaelea sp. \\
\hline 1005 & $\ldots$ & Raffaelea $\mathrm{sp}$. from Xyleborus affinis \\
\hline 1000 & 3649 & Raffaelea $\mathrm{sp}$. from $X$. ferrugineus \\
\hline 996 & 3645 & Raffaelea sp. from X. glabratus \\
\hline 999 & 3648 & Raffaelea sp. from X. glabratus \\
\hline 1006 & $\ldots$ & Raffaelea $\mathrm{sp}$. from Xyleborus sp. \\
\hline 1004 & RL5 & $\begin{array}{l}\text { Raffaelea sp. } \\
\text { from dead Persea americana }\end{array}$ \\
\hline 892 & C2401 & R. subalba \\
\hline 889 & $\mathrm{C} 2335$ & R. subfusca \\
\hline 895 & C593 & R. sulphurea \\
\hline 896 & CBS 726.69 & R. tritirachium \\
\hline
\end{tabular}

solution, $10.75 \mu \mathrm{l}$ of water, $1 \mu \mathrm{l}$ of LWD3 $10 \mu \mathrm{M}$ primer, $1 \mu \mathrm{l}$ of LWD4 $10 \mu \mathrm{M}$ primer, and $1 \mu \mathrm{l}$ of DNA template. All PCRs were replicated in triplicate with the $R$. lauricola serial dilution and noDNA negative control present on every run using an Eppendorf Mastercycler ep Realplex, and Realplex 2.0 software was used for all quantitative (q)PCR data analysis (Eppendorf Inc.).

Microsatellite-based detection method: sequencing and primer design. One-eighth of a Roche 454 GS FLX Titanium sequencer plate was used to generate sequences from $R$. lauricola isolate (PL716 gq996063) by the Interdisciplinary Center for Biotechnology Research (ICBR) at the University of Florida, Gainesville. Primer_designer.pl (5; modified by M. Gitzendanner) was used to find simple-sequence repeats, also known as microsatellites, and design primers to amplify them. Design parameters specified that each repeat contain a minimum of eight repeat units and primers not be located within $25 \mathrm{bp}$ of the repeat. The primers were then sorted by the number of repeats (large to small), repeat unit size (small to large), and product size (small to large). The 454 sequences were assembled using Geneious 5.4.6 de novo assembler using the high sensitivity option, with all other options left to default settings (3).

Microsatellite-based detection method: primer screening. Microsatellite primer pairs were first prescreened to limit the total number of PCRs. The prescreening consisted of testing the primer pairs with DNA from $R$. lauricola PL1390 to confirm that the correct amplicon was produced; and from its two closest relatives, $R$. brunnea (22) and Raffaelea sp. PL1004 (undescribed fungus that produced the false positive with the LWD1-LWD3 SSU-based method), to confirm that no amplicons were produced. Primer pairs that passed the prescreening were then tested against all of the isolates (Table 1). The primers were tested against DNA from Raffaelea spp. from the two clades closest to $R$. lauricola $(R$. montetyi, $R$. sulphurea, $R$. brunnea, R. ellipticospora, R. ambrosiae, $R$. subfusca, and $R$. fusca; 13) and included representatives ( $R$. subalba, $R$. tritirachium, $R$. albimanens, and $R$. arxii) from more distantly related clades (13). DNA from healthy redbay and avocado was included in the screening process to insure that the primers would not produce a false positive from host material.

The selected $R$. lauricola taxon-specific primer pairs, chk and ifw (GenBank KF381410 and KF381411 respectively), were further tested against nine isolates of $R$. lauricola. This was done to confirm that the primers produced the correct amplicon for all isolates. Six isolates were from the United States; three contained polymorphisms (PL388, PL692, and PL735) and three were identical to all other isolates (PL159, PL570, and PL571) according to an amplified fragment length polymorphism study (M. Hughes, personal communication). Two isolates, CBS 129001 and CBS 129006, from Taiwan, and one isolate, CBS 129007, from Japan (16), were also tested. The amplicons from the two primer pairs for the nine isolates were sequenced using Sanger sequencing at the University of Florida's ICBR.

Microsatellite-based detection method: PCR conditions. The optimal annealing temperature for the primer prescreening was determined by testing a range of temperatures $\left(60\right.$ to $\left.68^{\circ} \mathrm{C}\right)$. A temperature of $65^{\circ} \mathrm{C}$ was chosen as optimal because it was the highest temperature that did not reduce amplification and the higher temperature would increase PCR stringency when compared with the lower temperatures (41). The thermocycle profile consisted of $95^{\circ} \mathrm{C}$ for $180 \mathrm{~s}$, followed by 40 cycles of $95^{\circ} \mathrm{C}$ for $35 \mathrm{~s}$, $65^{\circ} \mathrm{C}$ for $30 \mathrm{~s}$, and $72^{\circ} \mathrm{C}$ for $60 \mathrm{~s}$, with a melting curve analysis performed upon completion. All PCRs used in this experiment were replicated in triplicate with $R$. lauricola positive controls and non-template negative controls present for every PCR run using an Eppendorf Mastercycler ep Realplex (Eppendorf Inc.). All PCR products were then visualized on agarose gels. Four DNA polymerases were tested: Biolase, (Bioline USA Inc.), AmpliTaq, AmpliTaq Gold, and AmpliTaq Gold 360 (Life Technologies Corp.), following the manufacturers' instructions for each. AmpliTaq Gold was used for the primer screening because it produced the lowest overall cycle threshold $(\mathrm{Ct})$ values. 
PCR reactions for the primer screening consisted of $2.5 \mu \mathrm{l}$ of GeneAmp 10× PCR Gold buffer (Life Technologies Corp.), $2.5 \mu \mathrm{l}$ of $2 \mathrm{mM}$ deoxynucleotide triphosphates (Bioline USA Inc.), $3 \mu \mathrm{l}$ of $25 \mathrm{mM} \mathrm{MgCl} 2,1 \mu \mathrm{l}$ of $10 \mathrm{mM}$ forward primer, $1 \mu \mathrm{l}$ of $10 \mathrm{mM}$ reverse primer, $0.4 \mu \mathrm{l}$ of $10 \times$ SYBR Green I solution (Lonza Inc.), $0.125 \mu \mathrm{l}$ of AmpliTaq Gold DNA polymerase (Life Technologies Corp.), $13.475 \mu \mathrm{l}$ of $\mathrm{H}_{2} \mathrm{O}$, and $1 \mu \mathrm{l}$ of DNA template. All of the primers used in this study were synthesized by Integrated DNA Technologies, Inc.

After the taxon-specific primers were chosen, a range of primer annealing temperatures $\left(60\right.$ to $\left.65^{\circ} \mathrm{C}\right)$ was tested. A fifth DNA polymerase, Immolase (Bioline USA Inc.) was also tested, which produced the same detection limit as Amplitaq Gold, produced more amplicons, costs less, and was used in subsequent testing. The PCRs were the same as above, except that $1.5 \mu \mathrm{l}$ of $50 \mathrm{mM} \mathrm{MgCl} 2$ and $14.975 \mu \mathrm{l}$ of $\mathrm{H}_{2} \mathrm{O}$ were used. The thermocycle profile for Immolase DNA polymerase consisted of $95^{\circ} \mathrm{C}$ for $4 \mathrm{~m}$, followed by 35 cycles of $95^{\circ} \mathrm{C}$ for $35 \mathrm{~s}, 65^{\circ} \mathrm{C}$ for $30 \mathrm{~s}$, and $72^{\circ} \mathrm{C}$ for $60 \mathrm{~s}$, with a melting curve analysis performed upon completion. The primer pairs chk and ifw (Table 2) were chosen for the diagnostic test because they did not produce amplicons in the presence of related taxa or host DNA and amplified well from $R$. lauricola DNA. The taxon-specific primers and the above methodology were tested in four independent laboratories (Carrie L. Harmon, Aaron J. Palmateer, Randy C. Ploetz, and Jason A. Smith) to confirm their reliability.

\section{Results}

SSU-based detection. The primers LWD1 and LWD3 (Table 2) produced an 832-bp amplicon and, when a $68^{\circ} \mathrm{C}$ primer annealing temperature was used, the primers did not produce amplicons in the presence of $R$. amasae, $R$. arxii, $R$. ellipticospora, $R$. fusca, $R$. montetyi, $R$. subalba, $R$. subfusca, $R$. sulphurea, or healthy redbay and avocado DNA. However, when used to examine a suspect, dead avocado tree in August 2009, they resulted in a spurious diagnosis for R. lauricola or laurel wilt. A fungus from this tree, Raffaelea sp. PL1004, resembled $R$. lauricola phenotypically and produced a SSU sequence (GenBank KF026302) that was $99 \%$ (971/980) similar to $R$. lauricola (JF797172, e-value of 0.00 ). However, it was not pathogenic to avocado in two pathogenicity tests (R. C. Ploetz, unpublished) and is now considered to be a closely related but undescribed Raffaelea $\mathrm{sp}$.

The qPCR primers LWD3 and LWD4 (Table 2) have a detection limit of $1 \times 10^{-4} \mathrm{ng}$ of $R$. lauricola $\mathrm{DNA}$ per qPCR. The standard curve constructed using the serial dilution $\left(6.3\right.$ to $1 \times 10^{-4} \mathrm{ng}$ per qPCR) produced a slope of -4.193 , PCR efficiency of $0.73, R^{2}$ of 0.997 , and $\mathrm{Ct}$ standard deviation of 0.64 at the lowest limit. There was no amplification or primer dimer formation with the no-DNA template, healthy avocado, or redbay-wood negative controls. However, at least one replicate of each related Raffaelea sp. tested produced an amplicon with approximately the correct melting temperature. However, the amplification occurred late in the amplification process (mean $\mathrm{Ct}$ values $>30$ ).

Microsatellite-based detection. During 454 sequencing, 80,237 reads were generated with an average length of $324 \mathrm{bp}$. Among the sequences, Primer_designer.pl found 3,103 microsatellites that contained fewer than eight repeat units, 3,117 microsatellites without suitable flanking primers, and 212 microsatellites with suitable primers. The sequences containing the chk and ifw loci were located in the 454 sequence assemblies to confirm that they were not in the same contig, adding evidence that they were located in different parts of the genome. Both of the R. lauricola taxon-specific primer pairs had a detection limit of $0.1 \mathrm{ng}$ of $R$. lauricola DNA per PCR and were able to quickly screen DNA from cultures but were not able to reliably detect $R$. lauricola from diseased wood samples (see Supplementary Figures 1 to 5 for all gel images and additional information). The primer pairs produced the correct amplicon for all isolates of $R$. lauricola that were tested. The six $R$. lauricola isolates from the southern United States and the three from Asia had identical DNA sequences for the ifw locus, and all except the CBS 129007 isolate from Japan, which had 14 additional TCT repeats, had the same chk sequences. All four labs and Carrillo et al. (4) were able to use the microsatellite-based detection method to screen suspect $R$. lauricola isolates, confirming the consistency of the methodology.

\section{Discussion}

Given the emergent nature of this pathogen and its potential threat to natural forests and avocado culture globally, surveillance programs have been initiated in several countries (Australia, Israel, Mexico and South Africa). The need for a practical diagnostic method that is consistently reliable in different labs is imperative. To date, diagnostic methodology has relied on sequencing of the LSU or SSU; however, the time and extra resources needed for this approach make it unrealistic for many diagnostic labs.

The false positive that was obtained with the SSU (LWD1 and LWD3 primers) and Raffaelea sp. (PL1004) illustrates the difficulty of designing taxon-specific PCR assays for new pathogens, as well as the dangers that are associated with the use of a single marker or locus for pathogen identification. These problems are especially acute when unknown, closely related taxa are present. To address these hurdles, microsatellite loci were used as the basis for a new method to detect $R$. lauricola. Microsatellites are ideal for such an objective because they have limited intertaxon transferability $(2,6)$, vary in length (33), and have been used previously to detect pathogens (1). In addition, numerous methods have been developed to locate microsatellites and design primers for their amplification $(26,38,42)$. The primers that were designed for the chk and ifw loci in the present study distinguished different isolates of $R$. lauricola from Asia and the United States from a wide array of closely related taxa. Their accuracy and successful use in four different laboratories demonstrates their value in identifying this pathogen and usefulness in diagnosing laurel wilt. Recently, Carrillo et al. (4) used the chk and ifw markers to verify the presence of $R$. lauricola in six xyleborine ambrosia beetles other than $X$. glabratus. The new microsatellite-based method reduced the time needed (from 1 week to 1 day) and cost of screening candidate $R$. lauricola isolates, because it eliminates the need for Sanger sequencing.

Despite the detection of the nonspecific amplicons late in the amplification cycles (mean Ct values $>30$ ), the qPCR assay (primers LWD3 and LWD4) is still useful due to the highly sensitive and nearly specific nature of this assay. For example, the assay could be used to assess the rate of spread of $R$. lauricola in different hosts or under different environmental conditions after artificial inoculation, and has been used to detect and quantify $R$. lauricola in a P. americana cultivar screening study (29).

The detection limits for the SSU and microsatellite methods were quite different ( 0.0001 versus $0.1 \mathrm{ng}$ per PCR, respectively). Some of this discrepancy may be due to differences in copy

Table 2. Primer pairs used in the study

\begin{tabular}{|c|c|c|c|c|}
\hline \multicolumn{2}{|r|}{ Forward primer } & \multicolumn{2}{|r|}{ Reverse primer } & \multirow[b]{2}{*}{ Amplicon size (bp) } \\
\hline Name & Sequence & Name & Sequence & \\
\hline chk-f & GTTCCACAGCCTGGAAAACC & chk-r & GGTAGAGGACGATGGTTGGC & $329-371$ \\
\hline ifw-f & TCGAGGTCGTGGACTACAGC & ifw-r & GTGGGACTCGCTGATGAGG & 322 \\
\hline LWD1 & CCCTGGTGATTCATGATAACTTCT & LWD3 & AACGCGTCAAAAGACAACAG & 832 \\
\hline LWD4 & TTTCTAGGACCGCCGTAATG & LWD3 & AACGCGTCAAAAGACAACAG & 232 \\
\hline
\end{tabular}


number between the PCR targets. rDNA loci have multiple copies and have been shown to vary (approximately 45 to 150) in some fungi $(11,32)$ while the microsatellite loci are assumed to be low in copy number. The increase in copy number means that less genomic DNA template is required for a PCR to reach the detection limit. This is one drawback of using low-copy loci for detection methods. Still, the difference in copy number does not explain all of the difference in detection limits.

Results with the rDNA SSU primers LWD1 and LWD3 demonstrate problems that can arise when detection of a new pathogen or disease is based on a single locus and undescribed, closely related taxa are present in host tissue. The $\mathrm{qPCR}$ primers LWD3 and LWD4 are not taxon specific and, therefore, cannot be used for diagnosing $R$. lauricola and laurel wilt. However, their high sensitivity and ability to quantitatively detect $R$. lauricola in wood samples makes them useful in experimental work with this pathogen (29). In contrast, the microsatellite-based assay is taxon specific. Although it is not sensitive enough to reliably detect the fungus in wood samples (titers of this pathogen are low in diseased tissue; 27), it can be used to quickly screen DNA from cultures for the presence of $R$. lauricola. The microsatellite assay is now used routinely in diagnostic clinics of the University of Florida, and is used by University of Florida researchers to experimentally verify the pathogen's presence in new host trees and ambrosia beetles.

\section{Acknowledgments}

Funding for this project was provided by the United States Department of Agriculture AFRI Biosecurity Program Project Number 2010-85605-20537. We thank members of the University of Florida Forest Pathology Laboratory, Tom Harrington, Jiri Hulcr, Patricia Lopez, Tom White, and the many collaborators that have provided assistance with this project.

\section{Literature Cited}

1. Abd-Elsalam, K., Bahkali, A. H., Moslem, M., De Wit, P. J. G. M., and Verreet, J. 2011. Detection of Mycosphaerella graminicola in wheat leaves by a microsatellite dinucleotide specific primer. Int. J. Mol. Sci. 12 1:682-693. http://www.mdpi.com/1422-0067/12/1/682/

2. Barbará, T., Palma-Silva, C., Paggi, G. M., Bered, F., Fay, M. F., and Lexer, C. 2007. Cross-species transfer of nuclear microsatellite markers: potential and limitations. Mol. Ecol. 16 18:3759-3767.

3. Biomatters. 2011. Geneious, version 5.4. http://www.geneious.com/

4. Carrillo, D., Duncan, R. E., Ploetz, J. N., Campbell, A. F., Ploetz, R. C., and Peña, J. E. 2013. Lateral transfer of a phytopathogenic symbiont among native and exotic ambrosia beetles. Plant Pathol. Online publication. doi:10.1111/ppa.12073

5. Castoe, T. A., Poole, A. W., Gu, W., Jason De Koning, A. P., Daza, J. M., Smith, E. N., and Pollock, D. D. 2010. Rapid identification of thousands of copperhead snake (Agkistrodon contortrix) microsatellite loci from modest amounts of 454 shotgun genome sequence. Mol. Ecol. Resour. 10:341-347.

6. Cristancho, M., and Escobar, C. 2008. Transferability of SSR markers from related Uredinales species to the coffee rust Hemileia vastatrix Genet. Mol. Res. 7:1186-1192.

7. Evans, E. A., Crane, J. H., Hodges, A., and Osborne, J. L. 2010. Potential economic impact of laurel wilt disease on the Florida avocado industry. HortTechnology 20:234-238.

8. Fraedrich, S. W., Harrington, T. C., Bates, C. A., Johnson, J., Reid, L. S., Best, G. S., Leininger, T. D., and Hawkins, T. S. 2011. Susceptibility to laurel wilt and disease incidence in two rare plant species, pondberry and pondspice. Plant Dis. 95:1056-1062.

9. Fraedrich, S. W., Harrington, T. C., and Rabaglia, R. J. 2004. Laurel wilt: a new and devastating disease of redbay caused by a fungal symbiont of the exotic redbay ambrosia beetle. Newsl. Mich. Entomol. Soc. 52:14-15.

10. Fraedrich, S. W., Harrington, T. C., Rabaglia, R. J., Ulyshen, M. D., Mayfield, A. E., III, Hanula, J. L., Eickwort, J. M., and Miller, D. R. 2008. A fungal symbiont of the redbay ambrosia beetle causes a lethal wilt in redbay and other Lauraceae in the southeastern United States. Plant Dis. 92:215224.

11. Ganley, A. R. D., and Kobayashi, T. 2007. Highly efficient concerted evolution in the ribosomal DNA repeats: total rDNA repeat variation revealed by whole-genome shotgun sequence data. Genome Res. 17:184-191.

12. Goldberg, N., and Heine, J. 2009. A comparison of arborescent vegetation pre-(1983) and post-(2008) outbreak of the invasive species the Asian ambrosia beetle Xyleborus glabratus in a Florida maritime hammock. Plant Ecol. Divers. 2:77-83.

13. Harrington, T. C., Aghayeva, D. N., and Fraedrich, S. W. 2010. New combinations in Raffaelea, Ambrosiella, and Hyalorhinocladiella, and four new species from the redbay ambrosia beetle, Xyleborus glabratus. Mycotaxon 111:337-361.

14. Harrington, T. C., and Fraedrich, S. W. 2010. Quantification of propagules of the laurel wilt fungus and other mycangial fungi from the redbay ambrosia beetle, Xyleborus glabratus. Phytopathology 100:1118-1123.

15. Harrington, T. C., Fraedrich, S. W., and Aghayeva, D. N. 2008. Raffaelea lauricola, a new ambrosia beetle symbiont and pathogen on the Lauraceae. Mycotaxon 104:399-404.

16. Harrington, T. C., Yun, H. Y., Lu, S., Goto, S. H., Aghayeva, D. N., and Fraedrich, S. W. 2011. Isolations from the redbay ambrosia beetle, Xyleborus glabratus, confirm that the laurel wilt pathogen, Raffaelea lauricola, originated in Asia. Mycologia 103:1028-1036.

17. Hughes, M., Smith, J. A., Mayfield, A. E., Minno, M. C., and Shin, K. 2011. First report of laurel wilt disease caused by Raffaelea lauricola on pondspice in Florida. Plant Dis. 95:1588.

18. Hughes, M. A., Shin, K., Eickwort, J., and Smith, J. A. 2012. First report of laurel wilt disease caused by Raffaelea lauricola on silk bay in Florida. Plant Dis. 96:910.

19. Hulcr, J., and Dunn, R. R. 2011. The sudden emergence of pathogenicity in insect-fungus symbioses threatens naive forest ecosystems. Proc. R. Soc. B 278:2866-2873

20. Inch, S. A., and Ploetz, R. C. 2012. Impact of laurel wilt, caused by Raffaelea lauricola, on xylem function in avocado, Persea americana. For Pathol. 42:239-245.

21. Justesen, A. F., Ridout, C. J., and Hovmoller, M. S. 2002. The recent history of Puccinia striiformis f. sp. tritici in Denmark as revealed by disease incidence and AFLP markers. Plant Pathol. 51:13-23.

22. Massoumi Alamouti, S., Tsui, C. K. M., and Breuil, C. 2009. Multigene phylogeny of filamentous ambrosia fungi associated with ambrosia and bark beetles. Mycol. Res. 113:822-835.

23. Mayfield, A.E., III. 2007. Laurel wilt: a serious threat to redbay and other related native plants. Palmetto 24:8-11.

24. Mayfield, A. E., III, Barnard, E. L., Smith, J. A., Bernick, S. C., Eickwort, J. M., and Dreaden, T. J. 2008. Effect of propiconazole on laurel wilt disease development in redbay trees and on the pathogen in vitro. Urban For. 35:317-324.

25. Mayfield, A. E., Smith, J. A., Hughes, M., and Dreaden, T. J. 2008. First Report of laurel wilt disease caused by a Raffaelea sp. on avocado in Florida. Plant Dis. 92:976.

26. Meglecz, E., Costedoat, C., Dubut, V., Gilles, A., Malausa, T., Pech, N., and Martin, J. F. 2010. QDD: A user-friendly program to select microsatellite markers and design primers from large sequencing projects. Bioinformatics 26:403-404.

27. Ploetz, R. C., Hulcr, J., Wingfield, M. J., and de Beer, Z. W. 2013. Destructive tree diseases associated with ambrosia and bark beetles: black swan events in tree pathology? Plant Dis. 97:856-872.

28. Ploetz, R. C., Pena, J. E., Smith, J. A., Dreaden, T. J., Crane, J. H., Schubert, T., and Dixon, W. 2011. Laurel wilt, caused by Raffaelea lauricola, is confirmed in Miami-Dade County, center of Florida's commercial avocado production. Plant Dis. 95:1589.

29. Ploetz, R. C., Pérez-Martínez, J. M., Smith, J. A., Hughes, M., Dreaden, T. J., Inch, S. A., and Fu, Y. 2012. Responses of avocado to laurel wilt, caused by Raffaelea lauricola. Plant Pathol. 61:801-808.

30. Rabaglia, R. J., Dole, S. A., and Cognat, A. I. 2006. Review of American Xyleborina (Coleoptera: Curculionidae: Scolytinae) occurring North of Mexico, with an illustrated key. Ann. Entomol. Soc. Am. 99:1034-1056.

31. Riggins, J. J., Hughes, M., Smith, J. A., Mayfield, A. E. I., Layton, B., Balbalian, C., and Campbell, R. 2010. First occurrence of laurel wilt disease caused by Raffaelea lauricola on redbay trees in Mississippi. Plant Dis. 94:634.

32. Rooney, A. P., and Ward, T. J. 2007. Highly efficient concerted evolution in the ribosomal DNA repeats: Total rDNA repeat variation revealed by whole-genome shotgun sequence data. Genome Res. 17:184-191.

33. Schlotterer, C. 2000. Evolutionary dynamics of microsatellite DNA. Chromosoma 109:365-371

34. Smith, J. A., Dreaden, T. J., Mayfield, A. E., Boone, A., Fraedrich, S. W. and Bates, C. 2009. First report of laurel wilt disease caused by Raffaelea lauricola on sassafras in Florida and South Carolina. Plant Dis. 93:1079.

35. Smith, J. A., Mount, L., Mayfield, A. E., Bates, C. A., Lamborn, W. A., and Fraedrich, S. W. 2009. First report of laurel wilt disease caused by Raffaelea lauricola on camphor in Florida and Georgia. Plant Dis. 93:198-198.

36. Spence, D. J., Smith, J. A., Mayfield, A. E., III, Hulcr, J., Ploetz, R., and Stelinski, L. L. 2013. Effect of chipping on emergence of the redbay ambrosia beetle (Coleoptera: Curculionidae: Scolytinae) and recovery of the laurel wilt pathogen from infested wood chips. J. Econ. Entomol. 106(5):2093-2100.

37. Surdick, J. A., and Jenkins, A. M. 2009. Pondspice (Litsea aestivalis) population status and response to laurel wilt disease in northeast Florida. Florida Natural Areas Inventory, Tallahassee, FL number 025665:42.

38. Thurston, M. I., and Field, D. 2005. Msatfinder: Detection and characterization of microsatellites. http://www.bioinformatics.org/ftp/pub/msatfinder/

39. U.S. Dep. Agric. 2013. Distribution of Counties with Laurel Wilt Disease* by Year of Initial Detection. U.S. Dep. Agric. For. Serv.

40. White, T. J., Bruns, T., Lee, S., and Taylor, J. 1990. Amplification and direct 
sequencing of fungal ribosomal RNA genes for phylogenetics. Pages 315322 in: PCR Protocols: A Guide to Methods and Application. M. A. Innis, D. H. Gelfand, J. J. Sninsky, and T. J. White, eds. Academic Press, San Diego, CA.

41. Wu, D. Y., Ugozzoli, L., Pal, B. K., Qian, J., and Wallace, R. B. 1991. The effect of temperature and oligonucleotide primer length on the specificity and efficiency of amplification by the polymerase chain reaction. DNA Cell Biol. 10:233-238.

42. You, F. M., Huo, N., Gu, Y. Q., Luo, M. C., Ma, Y., Hane, D., Lazo, G. R., Dvorak, J., and Anderson, O. D. 2008. BatchPrimer3: a high throughput web application for PCR and sequencing primer design. BMC Bioinf. 9:253. 